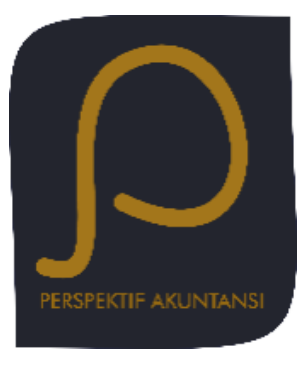

Perspektif Akuntansi

Volume 3 Nomor 3 (Oktober 2020), hal. 271-284

ISSN: 2623-0194(Print), 2623-0186(Online)

Copyright(C The Authors(s). All Rights Reserved

Center for Accounting Development and Research (CARD)

Fakultas Ekonomika dan Bisnis,

Universitas Kristen Satya Wacana

DOI: https://doi.org/10.24246/persi.v1i2.271-284

http://ejournal.uksw.edu/persi

\title{
Pengaruh Kepemilikan Manajerial Terhadap Kebijakan Pembagian Dividen Perbankan dengan Pemoderasi Tanggung Jawa Sosial Perusahaan
}

\author{
Nur Anita Chandra Putri ${ }^{1}$ \\ Kurnia Dewi Anggarhini \\ Universitas Sarjanawiyata Tamansiswa Yogyakarta
}

Received $21 / 02 / 2021$

Revised

$23 / 02 / 2021$

Accepted $28 / 02 / 2021$

\begin{abstract}
Currently, investment is an alternative to be able to benefit from the value invested. To be able to attract people to invest, a company must be able to take into account the dividends given so that people are increasingly interested in investing in companies without exception in banking sector companies. This study aims to analyze the factors that can influence dividend policy. This research aim to examine the effect of managerial ownership on dividend policy with corporate social responsibility as a moderating variable. The research's population in this is companies in the conventional banking sector that listed in Bursa Efek Indonesia (BEI) in the year 2015-2019. This research samples were to 8 companies with methods purposive sampling. The data were analyzed by making use of multiple linier analysis with the IBM SPSS application. The result of research indicate that managerial ownership has effect on dividend policy and corporate social responsibility does not moderate the effect of insider ownership on dividend policy.
\end{abstract}

Keywords: managerial ownership, dividend policy, corporate social responsibility 


\begin{abstract}
Abstrak. Saat ini, investasi merupakan salah satu alternatif untuk mendapatkan keuntungan dari nilai yang ditanamkan. Supaya dapat memberikan daya tarik masyarakat dalam melakukan investasi, maka suatu perusahaan harus dapat memperhitungkan dividen yang diberikan agar masyarakat semakin tertarik untuk melakukan investasi pada perusahaan tanpa terkecuali perusahaan sektor perbankan. Penelitian ini bertujuan untuk menganalisis faktor-faktor yang dapat mempengaruhi kebijakan dividen. Penelitian ini menguji dampak kepemilikan manajerial terhadap kebijakan dividen dengan tanggung jawab sosial sebagai pemoderasi. Populasi dalam penelitian ini adalah perusahaan sektor perbankan konvensional yang terdaftar di Bursa Efek Indonesia (BEI) pada tahun 2015-2019. Sampel penelitian berjumlah 8 perusahaan dengan metode purposive sampling. Data penelitian ini dianalisis dengan analisis linier berganda dengan menggunakan alat bantu IBM SPSS. Hasil penelitian ini membuktikan bahwa, 1) kepemilikan manajerial berpengaruh secara signifikan terhdapa kebijakan dividen, 2) tanggung jawab sosial perusahaan tidak memoderasi kepemilikan manajerial terhadap kebijakan dividen.
\end{abstract}

Kata kunci: kepemilikan manajerial, kebijakan dividen, tanggunfg jawab sosial perusahan.

\title{
Pendahuluan
}

Era modern seperti sekarang ini, investasi sudah cukup dikenal oleh masyarakat luas di Indonesia. Investasi sebagai salah satu langkah untuk dapat memberikan keuntungan dengan penanaman modal. Minat terhadap investasi pada masa sekarang ini semakin meningkat baik dikalangan pekerja maupun mahasiswa, karena dalam dunia perkuliahan juga sudah mulai dikenalkan dengan investasi. Investasi itu sendiri merupakan kegiatan menempatkan dana baik terhadap suatu aset maupun pada perusahaan dengan cara membeli saham, supaya bisa mendapatkan penghasilan atau peningkatan nilai dari investasi yang telah dilakukan (Hidayati, 2017).

Pada pembahasan investasi, pembagian dividen menjadi suatu topik yang diperbincangkan dan diperdebatkan di dalam keuangan dan dunia investasi. Dividen merupakan suatu tindakan timbal balik dari perusahaan terhadap para pemegang saham, karena sudah menanamkan modalnya (Samrotun, 2015). Penetapan kebijakan dalam hal pendistribusian dividen diperlukan untuk mengatur jumlah dividen yang nantinya akan dibagikan kepada pemegang saham (Sugeng, 2017). Dividen menjadi daya tarik utama bagi para pemegang saham, dimana pembagian dividen menjadi hal yang selalu dinantikan untuk 
mendapatkan timbal balik berupa keuntungan dari suatu penanaman modal. Ketetapan pembagian dividen perusahaan bersumber dari keuntungan yang dihasilkan, sehingga besar kecilnya pembagian dividen bergantung pada keuntungan dari suatu perusahaan (Hery, 2017). Keuntungan atau laba perusahaan menjadi salah satu faktor penting dalam hal pembagian dividen.

Pembagian dividen menjadi suatu harapan bagi pemegang saham untuk mendapatkan pengembalian dari penanaman investasi. Kebijakan penentuan pembagian dividen diperlukan untuk dapat mendistribusikan dividen secara tepat kepada pemegang saham (Samrotun, 2015). Penentuan dalam hal besar kecilnya jumlah pembagian dividen, merupakan kebijakan dari manajemen perusahaan yang dapat mempengaruhi nilai perusahaan dan harga pasar saham. Maka dalam hal pembagian dividen harus dipertimbangkan dengan sebaik-baiknya. Kemampuan perusahaan dalam membayar dividen, dapat meningkatkan nilai perusahaan. Pembagian dividen memberikan sinyal kepada pihak eksternal mengenai kondisi perusahaan. Semakin tinggi pembagian dividen maka akan memberikan sinyal positif bagi pihak eksternal, sehingga pihak eksternal memandang prospek perusahaan tersebut baik (Damayanti et al., 2017).

Kebijakan mengenai pembagian dividen menjadi salah satu tugas utama bagi pihak manajemen, terutama pihak manajer keuangan di dalam perusahaan. Dividen merupakan pembagian dari sejumlah pendapatan perusahaan terhadap pemegang saham, sehingga yang berkaitan secara langsung terhadap pembagian tersebut adalah bagian keuangan. Pihak manajemen memiliki peranan yang cukup penting yaitu dalam menentukan kebijakan mengenai pembagian dividen. Penetapan kebijakan dividen pada perusahaan bermanfaat dalam menjaga kepentingan para pemegang saham dan calon investor, karena penentuan kebijakan dividen ini harus dapat meyakinkan serta memberikan jaminan akan tercapainya tujuantujuan bagi para pemegang saham (Subagyo, et al., 2018).

Pada penetapan kebijakan pembagian dividen, terkadang terdapat perbedaan kepentingan di antara pihak manajemen sebagai agent dan pemegang saham sebagai principal (Rahmawati, 2016). Pihak manajemen lebih mementingkan pengembangan perusahaan, sehingga akan menggunakan laba yang diperoleh untuk pengembangan perusahaan dengan menetapkan laba ditahan. Namun pihak pemegang saham menginginkan keseluruhan laba yang diperoleh dapat dibagikan sebagai dividen. Perbedaan kepentingan antara manajer dengan pemegang saham menjadi masalah agensi dalam perusahaan, sehingga menyebabkan adanya rintangan dalam melaksanakan operasional perusahaan (Sudaryo et al., 2017).

Struktur kepemilikan pada perusahaan seperti kepemilikan manajerial dapat dijadikan sebagai alternatif dalam mengatasi permasalahan perbedaan kepentingan yang ada. Kepemilikan manajerial merupakan kepemilikan saham oleh pihak manajemen dengan pengukuran jumlah saham yang dimiliki. Kepemilikan saham oleh manajemen menjadikan pihak manajemen menjadi pihak agent dan juga principal (Wati, 2019). Kepemilikan manajerial ini dapat 
memberikan motivasi dalam meningkatkan kinerja untuk mengelola perusahaan dan dapat bertindak secara hati-hati ketika menetapkan sebuah kebijakan

Kepemilikan manajerial dalam perusahaan membuat pihak manajemen sebagai pemilik sekaligus pengelola akan dapat menyelaraskan kepentingannya dengan kepentingan para pemegang saham, sehingga masalah perbedaan kepentingan dapat dihindari (Juwitasari, 2013). Kepemilikan manajerial pada perusahaan dapat meningkatkan kualitas dalam pengambilan keputusan oleh manajer dan aktivitas manajer pada operasi perusahaan. Sebagai pengelola dan pemilik perusahaan, pihak manajemen dalam menentukan keputusan harus bersikap tegas, karena sebagai manajer sekaligus sebagai pemegang saham maka keputusan yang ditetapkan akan berdampak bagi dirinya sendiri.

Manajemen perusahaan memiliki tanggung jawab terhadap pembagian dividen kepada pemegang saham. Selain tanggung jawab mengenai pembagian dividen, suatu perusahaan juga memiliki tanggung jawab sosial. Tanggung jawab sosial perusahaan atau biasa disebut dengan corporate social responsibility (CSR) merupakan suatu gagasan bahwa perusahaan tidak hanya dihadapkan pada tanggungjawab dalam bentuk ekonomi atau nilai perusahaan saja, akan tetapi juga tanggung jawab terhadap masalah sosial dan lingkungan sekitar (Wati, 2019). Gagasan tentang CSR ini dimaksudkan supaya perusahaan lebih peduli dan dapat menjaga tanggung jawab sosial perusahaan terhadap lingkungan sekitar.

CSR menjadi bagian dari upaya perusahaan dalam memperlakukan para pemangku kepentingan dengan etis dan memberikan tanggung jawab secara sosial, ekonomi dan lingkungan. Kontribusi CSR memiliki kesinambungan dalam hal pembangunan ekonomi berkelanjutan untuk dapat memperbaiki kualitas hidup seluruh elemen (Hariyanto dan Al-Humaidy, 2017). Peningkatan reputasi atau citra perusahaan dapat dilakukan melalui penerapan CSR ini, dengan mengungkapkan informasi dan melakukan kegiatan peduli lingkungan maka perusahaan tersebut akan dipandang baik sehingga akan mendapatkan kepercayaan dari calon investor maupun pihak masyarakat (Arjana dan Suputra 2017).

Guna membantu dalam penetapan keputusan dalam pembagian dividen maka diperlukan penelitian lebih lanjut mengenai kebijakan pembagian tersebut. Penelitian ini dilakukan untuk menguji faktor kepemilikan manajerial dalam perusahaan terhadap kebijakan pembagian dividen dengan menggunakan studi kasus pada sektor perbankan, sedangkan penelitian terdahulu menggunakan perusahaan manufaktur. Penelitian mengenai kepemilikan manajerial terhadap kebijakan dividen masih berbeda-beda hasil yang diperoleh. Penelitian Sari dan Budiasih (2016) menunjukkan bahwa kepemilikan manajerial berpengaruh signifikan terhadap kebijakan dividen. Penelitian lain menunjukkan hasil yang berbeda seperti penelitian Yunisari (2018) kepemilikan manajerial tidak berpengaruh terhadap kebijakan dividen. Penggunaan variabel moderasi digunakan untuk menguji interaksi antara variabel independen dengan variabel dependen melalui pemoderasi tanggung jawab sosial perusahaan. Tanggung jawab 
sosial perusahaan digunakan sebagai variabel pemoderasi karena, semakin berkembangnya era sekarang ini yang mendorong perusahaan juga harus melaksanakan tanggung jawab terhadap lingkungan dan sosial. Dengan dilakukan penelitian ini supaya dapat memberikan kontribusi informasi mengenai pengaruh kepemilikan manajerial terhadap kebijakan pembagian dividen, penggunaan pemoderasi tanggung jawab sosial untuk mengetahui mengenai keterkaitan dalam pengaruh tersebut.

\section{Telaah Pustaka}

\section{Kebijakan Pembagian Dividen}

Kebijakan pembagian dividen menjadi suatu hal yang penting karena mempengaruhi jumlah tambahan pendanaan yang harus diperoleh perusahaan. Aspek utama dari suatu kebijakan dividen adalah menentukan alokasi dana yang tepat untuk pembayaran dividen kepada pemegang saham. Kebijakan pembagian dividen merupakan suatu kebijakan pada suatu perusahaan untuk menetapkan suatu keputusan mengenai pembagian besar kecilnya jumlah dividen kepada para pemegang saham (Sugeng, 2017). Besar kecilnya jumlah dividen yang dibagikan kepada para pemegang saham berdasarkan dari keputusan kebijakan dividen yang dirumuskan dan ditetapkan oleh tiap-tiap perusahaan (Pramana dan Sukartha, 2015).

Penentuan kebijakan dividen pada suatu perusahaan akan mempengaruhi daya tarik masyarakat atau calon investor untuk menetapkan pilihan dalam melakukan investasi pada suatu perusahaan. Maka besar kecilnya nilai dividen yang akan dibagikan kepada para pemegang saham, harus dipertimbangkan dengan sebaik mungkin sehingga dapat memberikan dampak yang positif bagi perusahaan (Sugeng, 2017). Pembagian dividen menjadi salah satu tindakan untuk dapat mengurangi konflik keagenan dimana perusahaan dapat memenuhi keinginan pemegang saham untuk mendapatkan dividen dan perusahaan mendapatkan kepercayaan dari pihak eksternal sehingga mereka tidak ragu untuk melakukan investasi pada perusahaan.

\section{Kepemilikan Manajerial}

Struktur kepemilikan manajerial dapat dijadikan sebagai salah satu cara untuk mengurangi ketidakseimbangan informasi antara pihak-pihak berkepentingan melalui adanya pengungkapan informasi di dalam perusahaan (Subagyo et al., 2018). Kepemilikan manajerial merupakan jumlah saham perusahaan yang dimiliki oleh pihak manajemen dengan pengukuran persentase kepemilikan saham. Adanya kepemilikan saham dari pihak manajemen dapat memiliki pengawasan terhadap kebijakan yang diambil oleh manajemen perusahaan. Struktur kepemilikan pada perusahaan menjadi aspek penting dalam mengatasi konflik kepentingan antara pihak stakeholder dengan manajemen perusahaan. Pihak manajerial memiliki peranan untuk melakukan pengembangan perusahaan 
dan melakukan strategi yang tepat. Manajerial dapat memastikan mengenai ideide baru dalam melakukan inovasi supaya dapat bertahan, bersaing dan berkembang lebih baik.

Perusahaan dengan pihak manajemen ikut sebagai pemegang saham akan lebih memiliki kualitas yang baik dalam pengambilan keputusan pada operasi perusahaan, dibandingkan dengan perusahaan yang tidak terdapat kepemilikan saham dari pihak manajemen (Darmayanti et al., 2018). Adanya kepemilikan manajerial menjadikan pihak manajemen ikut serta dalam penentuan keputusan dalam pengembangan suatu perusahaan. Pihak manajemen yaitu manajer memiliki peranan penting untuk melaksanakan perencanaan, pengorganisasian, pengarahan, pengawasan, serta pengambilan keputusan (Sukirni, 2012). Kepemilikan manajerial menjadikan pihak manajemen harus bersikap tegas dalam menentukan keputusan, karena sebagai manajer sekaligus sebagai pemegang saham maka keputusan yang ditetapkan juga akan berdampak bagi dirinya sendiri. Sehingga prinsip kehati-hatian harus diterapkan pada setiap pengambilan keputusan.

\section{Tanggung Jawab Sosial}

Tanggung jawab sosial perusahaan atau biasa dikenal dengan corporate social responsibility (CSR) merupakan suatu konsep yang mengarahkan agar seluruh aspek kegiatan bisnis memperhatikan kepentingan para pemangku kepentingan (stakeholder) terkait (Wati, 2019). Tanggung jawab sosial ini menunjukkan kepedulian perusahaan terhadap kepentingan pihak-pihak lain dan tidak hanya mementingkan kepentingan perusahaan semata. CSR merupakan komitmen perusahaan untuk mengelola bisnisnya supaya menghasilkan dampak yang positif terhadap masyarakat (Harsono, 2019). Hal ini menunjukkan bahwa, tujuan perusahaan untuk mengejar keuntungan juga harus tetap memperhatikan kepentingan orang banyak atau masyarakat luas.

CSR menjadi sebuah cara untuk mengintegrasikan dimensi sosial ke dalam strategi bisnis. Tanggung jawab sosial ini menjadi suatu dorongan untuk berbagi dengan sesama, bersama untuk maju, dan saling bekerja sama atau berkolaborasi dalam mencapai kesejahteraan bersama. CSR mengarahkan perusahaan untuk memaksimalkan manfaat dari kehadiran perusahaan bagi para stakeholder dan juga bagi perusahaan itu sendiri (Rachman, et al., 2011). Konsep tanggung jawab sosial berarti bahwa perusahaan harus bertanggung jawab atas tindakan dalam kegiatan bisnisnya agar tidak sampai merugikan pihak-pihak di masyarakat dan pada akhirnya dapat ikut menciptakan masyarakat yang sejahtera.

\section{Pengembangan hipotesis}

Struktur kepemilikan diyakini sebagai elemen potensial dari tata kelola perusahaan yang dapat mengatasi konflik kepentingan antara shareholder dengan manajemen (Rahmawati, 2016). Salah satu kategori struktur kepemilikan dalam perusahaan yaitu kepemilikan manajerial. Kepemilikan manajerial merupakan 
jumlah persentase saham yang dimiliki oleh pihak dalam perusahaan atau dari pihak manajemen. Manajer dalam hal ini memegang peranan yang penting, karena manajer melaksanakan perencanaan, pengorganisasian, pengarahan, pengawasan, serta pengambilan keputusan di dalam perusahaan (Wati, 2019). Kepemilikan manajerial dapat dijadikan sebagai suatu mekanisme dalam mengurangi konflik keagenan, karena dengan adanya kepemilikan manajerial ini dapat menghilangkan perilaku oportunistik manajer dan juga dapat menyelaraskan kepentingan antara agent dan principal.

Kepemilikan manajerial menjadikan pihak manajemen terlibat dalam kepemilikan saham perusahaan. Adanya kepemilikan saham akan memberikan motivasi dalam meningkatkan kinerja untuk mengelola perusahaan dan dapat bertindak secara hati-hati dalam menetapkan sebuah kebijakan (Rahayu dan Rusliati, 2019). Kepemilikan manajerial dapat mengurangi masalah keagenan, dimana dengan kepemilikan saham oleh pihak manajemen akan mengurangi adanya kepentingan sepihak, sehingga kepentingan yang ada antara pihak manajemen dengan pemegang saham akan sejajar (Ratih dan Damayanthi, 2016). Penelitian Yunisari (2018) pada perusahaan manufaktur memperoleh hasil bahwa kepemilikan manajerial tidak berpengaruh terhadap kebijakan dividen. Berbeda dengan penelitian Simanjuntak dan Kiswanto (2015) yang memperoleh hasil bahwa kepemilikan manajerial berpengaruh terhadap penentuan kebijakan pembagian dividen. Berdasarkan penjelasan di atas maka hipotesis yang dirumuskan adalah sebagai berikut:

$\boldsymbol{H}_{1}$ : Kepemilikan manajerial berpengaruh terhadap kebijakan pembagian dividen

Keberadaan perusahaan di tengah lingkungan masyarakat berpotensi besar untuk mengubah lingkungan masyarakat, baik ke arah negatif maupun kearah positif. Dengan demikian perusahaan perlu untuk mencegah timbulnya dampak negatif, karena dapat memicu konflik dengan masyarakat yang nantinya akan dapat mengganggu jalannya perusahaan dan aktivitas masyarakat (Budiarti and Raharjo, 2014). Tanggung jawab sosial perusahaan hadir sebagai salah satu bentuk komitmen untuk dapat berkontribusi terhadap masyarakat sehingga dapat menimbulkan dampak yang positif bagi lingkungan masyarakat. Perusahaan dapat melakukan tindakan dengan meminimalisir dampak negatif dan memaksimalkan dampak positif terhadap seluruh pemangku kepentingan (Suparman, 2013).

Penerapan tanggung jawab sosial perusahaan dapat dijadikan sebagai suatu standar yang menjadikan perusahaan memperoleh citra baik dari masyarakat, sehingga memberikan benefit bagi perusahaan (Kadir, 2015). Semakin berkembangnya era modern seperti sekarang, perusahaan memiliki kewajiban dalam hal pemenuhan tanggung jawab sosial terhadap lingkungan sekitar. Pelaksanaan tanggung jawab sosial akan dapat membantu dalam memperbaiki kualitas perusahaan dipandangan pihak eksternal. Pemenuhan hal tersebut perlu untuk dipertimbangkan dengan teliti oleh pihak manajemen demi tercapainya perkembangan usaha. Hubungan timbal balik yang tercipta antara perusahaan 
dengan pihak eksternal akan mencapai kesejahteraan bersama. Pihak berkepentingan atau stakeholder dan perusahaan saling bekerjasama guna meningkatkan kualitas hidup, dengan jalinan kerjasama ini maka akan tercipta keselarasan antara perusahaan dengan pihak stakeholder (Sudarsana, 2018). Berdasarkan uraian di atas, maka perumusan hipotesis adalah sebagai berikut:

$\boldsymbol{H}_{2}$ : Tanggung jawab sosial perusahaan memoderasi pengaruh kepemilikan manajerial terhadap kebijakan pembagian dividen

\section{Metoda}

\section{Jenis Penelitian}

Penelitian ini merupakan jenis penelitian kuantitatif, untuk menguji pengaruh kepemilikan manajerial terhadap pembagian dividen dengan variabel moderasi tanggung jawab sosial perusahaan dengan studi kasus pada perbankan konvensional yang terdaftar di Bursa Efek Indonesia periode tahun 2015-2019. Penelitian kuantitatif adalah penelitian yang menggunakan data berupa angka dengan model-model matematis dan dianalisis dengan menggunakan statistic

Data dan Sumber Data

Data penelitian menggunakan data sekunder berupa laporan keuangan tahunan perusahaan sektor perbankan konvensional yang telah dipublikasikan pada periode tahun 2015-2019. Data diperoleh dari website Bursa Efek Indonesia (BEI) yaitu www.idx.co.id. Data yang digunakan berupa kepemilikan saham manajemen, dividen, dan pengungkapan tanggung jawab sosial perusahaan.

\section{Populasi dan Sampel}

Populasi pada penelitian ini adalah perusahaan perbankan konvensional yang terdaftar di Bursa Efek Indonesia (BEI). Sedangkan sampel yang digunakan yaitu perusahaan perbankan konvensional yang terdaftar di Bursa Efek Indonesia (BEI) pada tahun 2015-2019. Teknik pengambilan sampel dilakukan dengan teknik purposive sampling, dimana pengambilan sampel menggunakan kriteria khusus sesuai dengan tujuan penelitian. Kriteria sampel yang digunakan dalam penelitian ini sesuai dengan ketentuan sebagai berikut: data yang digunakan hanya sebatas perusahaan perbankan konvensional yang terdaftar di Bursa Efek Indonesia (BEI); perusahaan perbankan yang digunakan secara aktif mempublikasikan laporan keuangan perusahaan di Bursa Efek Indonesia (BEI); dan terdapat data yang diperlukan di laporan keuangan perusahaan perbankan dalam sampel yang digunakan.

\section{Pengukuran Variabel}

Penelitian ini menggunakan variabel independen berupa kepemilikan manajerial, variabel dependen adalah kebijakan pembagian dividen, dan variabel pemoderasi adalah tanggung jawab sosial perusahaan. Pengukuran untuk masing-masing variabel adalah sebagai berikut: 
Tabel 1. Pengukuran Variabel

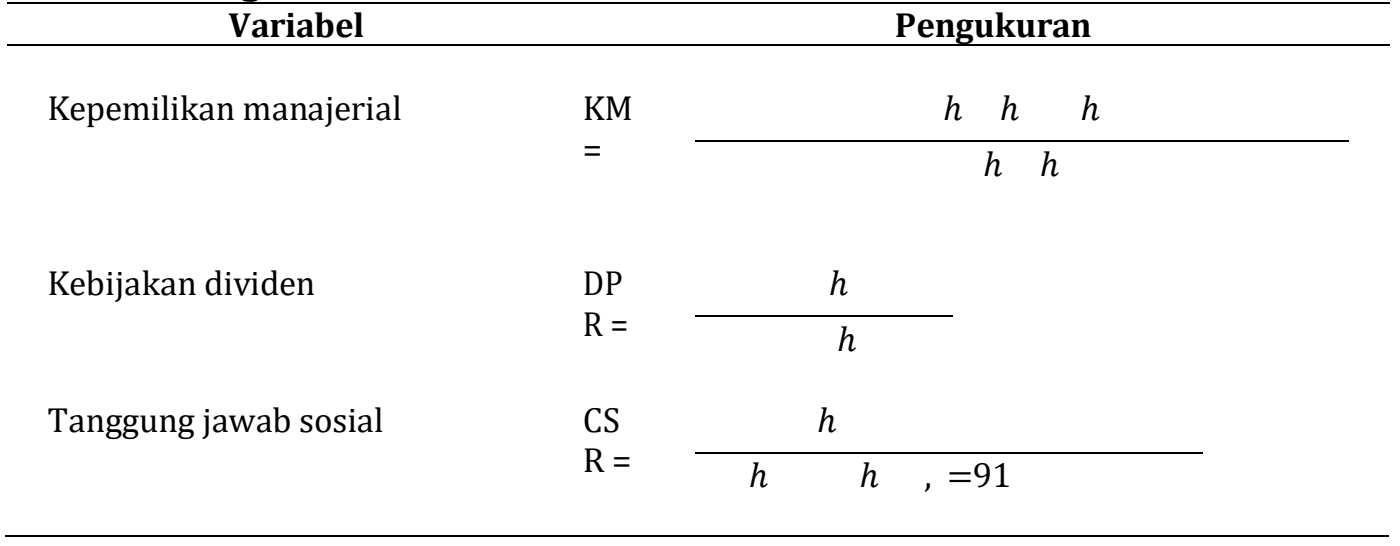

\section{Teknik Analisis Data}

Analisis data pada penelitian ini terdiri dari pengujian asumsi klasik dan pengujian hipotesis dengan analisis regresi linier berganda yang menggunakan alat bantu IBM SPSS. Uji asumsi klasik pada penelitian ini terdiri dari uji normalitas, uji multikolinearitas, uji heteroskedastisitas, dan uji autokolerasi. Keseluruhan pengujian tersebut digunakan untuk menguji kenormalan penyebaran suatu data statistik. Apabila hasil pengujian menunjukkan nilai signifikansi $\geq 0,05$ pada uji normalitas, uji heteroskedastisitas, dan uji auto kolerasi juga menghasilkan nilai VIF $<10$ dan tolerance value $>0,1$ pada uji multikolinearitas, maka penyebaran data yang dianalisis normal dan dapat dilakukan penelitian lebih lanjut.

Pengujian hipotesis variabel moderasi pada penelitian ini menggunakan uji Moderated Regression Analysis (MRA). Uji Moderated Regression Analysis (MRA) merupakan pengujian yang digunakan untuk menguji variabel moderasi di mana pada persamaan regresinya mengandung unsur interaksi yaitu perkalian antara variabel independen dengan variabel moderasi. 


\section{Hasil dan Pembahasan}

\section{Hasil}

\section{Statistik deskriptif}

Berdasarkan hasil output SPSS pada Tabel 2, variabel kepemilikan manajerial memiliki nilai minimum 0,000 dan nilai maksimum 0,007 . Nilai mean yang dihasilkan 0,001 dengan standar deviasi 0,001 yang artinya bahwa penyebaran data dari kepemilikan manajerial adalah 0,001 dari 35 data.

Tabel 2. Statistik Deskriptif

\begin{tabular}{lccccc}
\hline & N & Minimum & Maximum & Mean & $\begin{array}{c}\text { Std. } \\
\text { Deviation }\end{array}$ \\
\hline KM & 35 & 0.000 & 0.007 & 0.001 & 0.001 \\
DPR & 35 & 0.000 & 0.380 & 0.219 & 0.101 \\
CSR & 35 & 0.110 & 0.341 & 0.217 & 0.064 \\
Valid N & 35 & & & & \\
(listwise) & & & & & \\
\hline
\end{tabular}

Sedangkan variabel dividen memiliki nilai minimum 0,000 dan nilai maksimum 0,380. Nilai mean dari dividen adalah 0,219 dengan standar deviasi 0,101 yang artinya bahwa penyebaran data dari dividen adalah 0,101 dari 35 data. Variabel pemoderasi yaitu tanggung jawab sosial perusahaan memiliki nilai minimum 0,110 dan nilai maksimum 0,341. Nilai mean 0,217 dengan standar deviasi 0,064 yang artinya bahwa penyebaran data dari tanggungjawab sosial perusahaan adalah 0,064 dari 35 data.

\section{Pengujian Asumsi Klasik}

Berdasarkan hasil output SPSS pada Tabel 3, menunjukkan bahwa hasil dari uji normalitas Kolgomoro-Smirnov (K-S) memperoleh nilai Asymp. Sig. (2-tailed) sebesar 0,151 > 0,05. Hal ini berarti bahwa pengujian normalitas dengan Kolgomoro-Smirnov (K-S) menunjukkan data yang terdistribusi normal. 


\begin{tabular}{ccc}
\hline \multicolumn{1}{c}{$\mathbf{N}$} & & Unstandardized Residual \\
\hline Normal Parametersa,b & Mean & 35 \\
& Std. Deviation & .0000000 \\
Most Extreme Differences & Absolute & .09391568 \\
& Positive & .192 \\
& Negative & .115 \\
Kolmogorov-Smirnov Z & -.192 \\
Asymp. Sig. (2-tailed) & .131
\end{tabular}

Sumber: Data Diolah (2021)

Tabel 4. Uji Multikolinearitas

\begin{tabular}{cccc}
\hline & Model & \multicolumn{2}{c}{ Collinearity Statistics } \\
\hline \multirow{2}{*}{$\mathbf{1}$} & Kepemilikan Manajerial & Tolerance & VIF \\
& CSR & .906 & 1.104 \\
& & .906 & 1.104 \\
\hline
\end{tabular}

Sumber: Data Diolah (2021)

Kemudian, berdasarkan output dari SPSS pada Tabel 4, bahwa VIF untuk setiap variabel memiliki nilai di bawah 10 dan nilai tolerance berada di atas 0,1 . Variabel kepemilikan manajerial dan CSR memiliki nilai yang sama yaitu, nilai VIF sebesar 1,104 dan nilai tolerance sebesar 0,906. Hal ini menunjukkan bahwa hasil pengujian ini tidak terjadi masalah multikolinearitas.

Tabel 5. Uji Heteroskedastisitas

\begin{tabular}{|c|c|c|c|c|c|}
\hline \multirow[t]{2}{*}{ Model } & \multicolumn{2}{|c|}{$\begin{array}{l}\text { Unstandardized } \\
\text { Coefficients }\end{array}$} & \multirow{2}{*}{$\begin{array}{c}\text { Standardized } \\
\text { Coefficients } \\
\text { Beta } \\
\end{array}$} & \multirow[t]{2}{*}{$\mathbf{t}$} & \multirow[t]{2}{*}{ Sig. } \\
\hline & B & Std. Error & & & \\
\hline 1 (Constant) & .052 & .043 & & 1.221 & .231 \\
\hline Kepemilikan & -6.010 & 9.866 & -.112 & -.609 & .547 \\
\hline $\begin{array}{l}\text { Manajerial } \\
\text { CSR }\end{array}$ & .095 & .180 & .096 & .526 & .603 \\
\hline
\end{tabular}

Sumber: Data Diolah (2021)

Berdasarkan output SPSS dari Tabel 5, bahwa nilai signifikansi variabel yang ada lebih dari 0,05. Variabel kepemilikan manajerial memiliki nilai signifikansi sebesar 0,547 dan CSR memiliki nilai signifikansi sebesar 0,603. Hal ini menunjukkan bahwa model regresi ini tidak terdapat masalah heterokedastisitas. 


\section{Tabel 6. Uji Autokolerasi}

\begin{tabular}{lc}
\hline & Unstandardized Residual \\
\hline Test Value & -.00736 \\
Cases < Test Value & 17 \\
Cases >= Test Value & 18 \\
Total Cases & 35 \\
Number of Runs & 16 \\
$\mathbf{Z}$ & Unstandarized Residual \\
Asymp. Sig. (2-tailed) & .495 \\
\hline Sumber: Data diolah (2021)
\end{tabular}

Sumber: Data diolah (2021)

Berdasarkan output SPSS dari Tabel 6 dengan pengujian menggunakan runs test, nilai Asymp. Sig. (2-tailed) sebesar 0,495 >0,05. Hal ini menunjukkan bahwa pada model regresi ini tidak terdapat masalah auto kolerasi.

\section{Pengujian Hipotesis}

Berdasarkan output SPSS pada Tabel 7, variabel kepemilikan manajerial memiliki nilai signifikansi sebesar 0,040 dimana nilai tersebut di bawah nilai $\alpha$ yaitu sebesar 0.05. Sehingga dapat disimpulkan bahwa kepemilikan manajerial memiliki pengaruh terhadap kebijakan pembagian dividen.

\section{Tabel 7. Uji Hipotesis}

\begin{tabular}{|c|c|c|c|c|c|}
\hline \multirow[t]{2}{*}{ Model } & \multicolumn{2}{|c|}{$\begin{array}{l}\text { Unstandardized } \\
\text { Coefficients }\end{array}$} & \multirow{2}{*}{$\begin{array}{c}\text { Standardized } \\
\text { Coefficients } \\
\text { Beta } \\
\end{array}$} & \multirow[t]{2}{*}{$t$} & \multirow[t]{2}{*}{ Sig. } \\
\hline & B & Std. Error & & & \\
\hline 1 (Constant) & .238 & .019 & & 12.776 & .000 \\
\hline $\begin{array}{l}\text { Kepemilikan } \\
\text { Manajerial }\end{array}$ & -30.390 & 14.236 & -.348 & -2.135 & .040 \\
\hline CSR & -.434 & .334 & -.273 & -1.299 & .203 \\
\hline $\begin{array}{l}\text { Interaksi } \\
\mathrm{KM}^{*} \mathrm{CSR}\end{array}$ & 507.724 & 518.414 & .971 & .979 & .335 \\
\hline
\end{tabular}

Sumber: Data Diolah (2021)

Sedangkan hasil pengujian variabel moderasi mengenai interaksi dari variabel kepemilikan manajerial dengan CSR memiliki nilai sigifikansi sebesar 0,335 yang lebih besar dari batas nilai $\alpha$ yaitu sebesar 0,05. Sehingga dapat disimpulkan bahwa variabel CSR tidak dapat memoderasi pengaruh kepemilikan manajerial terhadap kebijakan pembagian dividen. 


\section{Pembahasan}

Hasil uji hipotesis menunjukkan variabel kepemilikan manajerial berpengaruh signifikan terhadap kebijakan pembagian dividen perbankan dengan nilai signifikansi yang diperoleh sebesar 0,040 <0,05, maka H1 diterima. Arah pengaruh yang dihasilkan yaitu negatif dilihat dari nilai t yaitu -2.135 , dimana nilai tersebut bernilai negatif. Kepemilikan manajerial yang ada akan memberikan peran ganda kepada manajer yaitu sebagai seorang manajer dan juga pemegang saham. Peran ganda ini dapat memberikan fungsi monitoring dan memperkecil asymetric information, juga akan mendorong manajer untuk bertindak hati-hati karena mereka akan menanggung konsekuensi dari setiap keputusan yang ditetapkan.

Kepemilikan manajerial dapat dijadikan sebagai suatu mekanisme dalam mengurangi konflik keagenan, karena dengan adanya kepemilikan manajerial ini dapat menghilangkan perilaku oportunistik manajer dan juga dapat menyelaraskan kepentingan antara agent dan principal (Rahmawati, 2016). Kepemilikan manajerial di dalam perusahaan memberikan banyak pertimbangan kepada pihak manajemen untuk menetapkan suatu keputusan. Manajemen dengan memiliki saham perusahaan akan mempertimbangkan kebijakan guna perkembangan usaha, melakukan penahanan pembagian dividen akan membantu untuk perkembangan usaha sehingga dapat menghasilkan keuntungan yang lebih besar bagi perusahaan kedepannya.

Hasil statistik variabel moderasi menunjukkan bahwa CSR tidak dapat memoderasi pengaruh kepemilikan manajerial terhadap kebijakan pembagian dividen, sehingga hipotesis yang diajukan ditolak. Pengungkapan CSR pada perusahaan perbankan hanya sebatas mengungkapkan dengan melakukan kegiatan-kegiatan sosial tanpa memperhatikan adanya indikator pengukuran yang terdapat pada indeks CSR (Marthin et al., 2018). Hal ini terbukti bahwa variabel pengungkapan CSR memiliki nilai minimum 0,099 dan nilai maksimum sebesar 0,352 , dengan nilai rata-rata sebesar 0,20818. Nilai tersebut menunjukkan bahwa sebaran data CSR terlalu kecil, sehingga tidak mampu untuk memoderasi pengaruh variabel kepemilikan manajerial terhadap kebijakan pembagian dividen.

\section{Simpulan}

Penelitian ini menguji pengaruh kepemilikan manajerial terhadap kebijakan pembagian dividen dengan pemoderasi tanggung jawab sosial perusahaan yang menggunakan studi kasus perbankan konvensional terdaftar di Bursa Efek Indonesia pada tahun 2015-2019. Berdasarkan dari hasil pengujian, maka dapat disimpulkan bahwa: Kepemilikan manajerial berpengaruh terhadap kebijakan pembagian dividen. Kepemilikan manajerial pada perusahaan menunjukkan bahwa pihak manajemen ikut serta dalam kepemilikan saham perusahaan, maka pihak manajemen sebagai pihak agent sekaligus juga sebagai pihak principal. Hal ini membuat pihak manajemen memiliki wewenang dalam setiap pengambilan keputusan, dengan kepemilikan manajerial pada perusahaan akan mempengaruhi 
kebijakan yang akan ditetapkan termasuk kebijakan pembagian dividen. Pihak manajemen dengan kepemilikan sahamnya berperan sebagai pemilik perusahaan sehingga akan lebih mempertimbangkan untuk mengembangkan usahanya. Perkembangan usaha tersebut akan lebih memberikan keuntungan yang besar daripada dengan mementingkan pembagian dividen.

Tanggung jawab sosial perusahaan tidak dapat memoderasi pengaruh kepemilikan manajerial terhadap kebijakan pembagian dividen. Variabel CSR tidak dapat memoderasi pengaruh kepemilikan manajerial terhadap kebijakan pembagian dividen dikarenakan perusahaan kurang memperhatikan standar yang ada pada pengungkapan CSR. Perusahaan hanya melakukan kegiatan yang tidak terdapat dalam kriteria yang ada, seperti menanam pohon, penanggulangan bencana alam, dan lain-lain. Kegiatan tersebut tidak termasuk dalam kriteria aspek dalam CSR sehingga nilai yang dihasilkan dari CSR kecil menjadikan sebaran data yang tidak cukup untuk memoderasi antara variabel dependen dengan variabel dependen.

Penelitian ini terbatas pada variabel yang digunakan untuk menguji kebijakan pembagian dividen adalah kepemilikan manajerial dan pemoderasi tanggung jawab sosial perusahaan. Bagi penelitian selanjutnya mungkin dapat menguji dengan menggunakan variabel kontrol atau menambahkan variabel lain. Saran bagi penelitian selanjutnya yaitu, memperluas studi kasus yang digunakan sehingga sektor-sektor yang ada dapat terwakilkan, menggunakan pengukuran variabel yang berbeda, dan dapat melakukan penambahan variabel lain yang mungkin dapat memberikan pengaruh yang lebih baik terhadap kebijakan pembagian dividen.

\section{Daftar Pustaka}

Arjana, I. Putu Pande Hari, and I. D. G. Dharma Suputra. 2017. "Pengaruh Profitabilitas Leverage, Ukuran Perusahaan Dan Corporate Social Responsibility Pada Kebijakan Dividen.” E-Jurnal Akuntansi Universitas Udayana 21(3):2021-51.

Budiarti, Meilanny, and Santoso Tri Raharjo. 2014. "Corporate Social Responsibility (CSR) Dari Sudut Pandang Perusahaan."

Damayanti, Ratna, Fithri Setya Marwati, and Rochmi Widayanti. 2017. "Analisa Kebijakan Dividen Berdasarkan Teori Lintner." 183-94.

Darmayanti, Fella Eka, Fauzi Sanusi, and Ika Utami Widya. 2018. "Pengaruh Kepemilikan Manajerial, Kepemilikan Institusional, Dan Kebijakan Hutang Terhadap Nilai Perusahaan (Studi Pada Perusahaan Manufaktur Yang Terdaftar Di Bursa Efek Indonesia Periode 2011-2015)." XI.

Ghozali, I. 2018. Aplikasi Analisis Multivariate Dengan Program IBM SPSS 25. 9th ed . edited by T. A. Semarang: Badan Penerbit Universitas Diponegoro.

Hariyanto, Erie, and Ali Al-Humaidy. 2017. Pelaksanaan Corporate Social Responsibility (CSR) Dan Zakat Perusahaan Pada Lembaga Keuangan Syari'ah. edited by M. Afandi. Madura: Duta Media Publishing.

Harsono, Sudasi. 2019. Comdev (Community Development), CSR (Corporate Sosial Responsibility), Dan PPM (Pengembangan Dan Pemberdayaan Masyarakat) Dalam Harapan, Kendala, Dan Pelaksanaannya. Yogyakarta: Penerbit Kalika.

Hery. 2017. Kajian Riset Akuntansi. edited by A. Pramono. Jakarta: PT Grasindo. 
Hidayati, Amalia Nuril. 2017. "Investasi: Analisis Dan Relevansinya Dengan Ekonomi Islam." 8(2):227-41.

Juwitasari, Arinda. 2013. "Kepemilikan Manajerial Perusahaan Manufaktur Di Bursa Efek Indonesia (BEI)."

Kadir, Nuryadi. 2015. "Perusahaan 'Antara Praktek Bisnis Dan Praktek Sosial ' ( Studi Penerapan Corporate Social Responsibility Di Indonesia ).” Jurnal Dakwah Tabligh 16(1):20-30.

Marthin, Marthen B. Salinding, and Inggit Akim. 2018. "Implementasi Prinsip Corporate Social Responsibility (Csr) Berdasarkan Undang-Undang Nomor 40 Tahun 2007 Tentang Perseroan Terbatas." Journal of Private and Commercial Law 1(1):11131.

Pramana, Gede Rian Aditya, and I. Made Sukartha. 2015. “Analisis Faktor-Faktor Yang Mempengaruhi Kebijakan Dividen Di Bursa Efek Indonesia.” E-Jurnal Akuntansi Universitas Udayana 221-32.

Rachman, Nurdizal M., Asep Efendi, and Emir Wicaksana. 2011. Panduan Lengkap Perencanaan CSR. Jakarta: Penebar Swadaya.

Rahayu, Dewi, and Ellen Rusliati. 2019. "Kepemilikan Institusional, Kepemilikan Manajerial, Dan Ukuran Perusahaan Terhadap Kebijakan Dividen." Jurnal Riset Akuntansi Kontemporer 11(1):41-47.

Rahmawati, Syarifah. 2016. Konflik Keagenan Dan Tata Kelola Perusahaan Di Indonesia. edited by Faisal. Banda Aceh: Syiah Kuala University Press.

Ratih, I. Dewa Ayu, and I. Gusti Ayu Eka Damayanthi. 2016. “Kepemilikan Manajerial Dan Profitabilitas Pada Nilai Perusahaan Dengan Pengungkapan Tanggung jawab Sosial Sebagai Variabel Pemoderasi." E-Jurnal Akuntansi Universitas Udayana 14(2):1510-38.

Riyanto, Slamet, and Aglis Andhita Hatmawan. 2020. Metode Riset Penelitian Kuantitatif Penelitian Di Bidang Manajemen, Teknik, Pendidikan, Dan Eksperimen. Yogyakarta: CV BUDI UTAMA.

Samrotun, Yuli Chomsatu. 2015. "Kebijakan Dividen Dan Faktor-Faktor Yang Mempengaruhinya." Jurnal Paradigma 13(1):92-102.

Sari, Ni Komang Ayu Purnama, and I. Gusti Ayu Nyoman Budiasih. 2016. "Pengaruh Kepemilikan Manajerial , Kepemilikan Institusional , Free Cash Flow Dan Profitabilitas Pada Kebijakan Dividen." E-Jurnal Akuntansi Universitas Udayana 15(3):2439-66.

Simanjuntak, Damaris, and Kiswanto. 2015. "Determinan Kebijakan Dividen Pada Perusahaan Manufaktur Di Indonesia Tahun 2011-2013.” Jurnal Dinamika Akuntansi 2:150-60.

Subagyo, Nur Aini Masruroh, and Indra Bastian. 2018. Akuntansi Manajemen Berbasis Desain. Yogyakarta: Gadjah mada University Press.

Sudarsana. 2018. "Tinjauan Teoritis Tentang Implementasi Tanggung Jawab Sosial Perusahaan." Dialektika Masyarakat: Jurnal Sosiologi 2(1):83-103.

Sudaryo, Yoyo, Devyanthi Sjarif, and Nunung Ayu Sofiati. 2017. Keuangan Di Era Otonomi Daerah. edited by P. Christian. Yogyakarta: Penerbit Andi.

Sugeng, Bambang. 2017. Manajemen Keuangan Fundamental. Yogyakarta: CV BUDI UTAMA.

Sukirni, Dwi. 2012. "Kepemilikan Manajerial, Kepemilikan Institusional, Kebijakan Dividen, Dan Kebijakan Hutang Analisis Terhadap Nilai Perusahaan.” 1.

Suparman. 2013. "Corporate Social Responsibility : Bentuk Tanggung Jawab Sosial Dan Kepedulian Perusahaan Dengan Masyarakat."

Wati, Lela Nurlaela. 2019. Model Corporate Social Responsibility (CSR). edited by Momon. Jawa Timur: Myria Publisher.

Widarjono. 2010. Analisis Statistika Multivariat Terapan. Yogyakarta: UPP STIM YKPN.

Yunisari, Ni Wayan. 2018. "Pengaruh Profitabilitas Dan Kepemilikan Manajerial Pada Kebijakan Dividen Dengan Likuiditas Sebagai Variabel Moderasi.” E-Jurnal Akuntansi Universitas Udayana 23(1):379-405. 